\title{
KONSEP PENGEMBANGAN METODE DAKWAH MODERN
}

\author{
ERA FASIRA
}

\author{
Institute Agama Islam Negeri Parepare,Fakultas ushuluddin Adab dan \\ Dakwah,Program Studi Komunikasi Penyiaran Islam
}

Email:erafasira001@iainpare.ac.id

\begin{abstract}
Abstrak
Artikel ini membahas tentang dakwah dalam masyarakat di era modern yang saat ini sedang mengalami masalah. Pengembangan metode dakwah juga harus mengikuti era saat ini bahkan lebih dengan cara pemanfaatan teknologi komunikasi menjadi tolok ukur pengembangan. Di masa lalu dan sekarang tentu saja juga berbeda terutama metode ceramah dan pendidikan Islam secara langsung oleh para Ulama, Ustad, Tengku dan ahli agama lainnya tentu saja sangat sering kita temui. Namun, saat ini sistem informasi yang semakin maju akan memudahkan orang-orang dari semua lapisan masyarakat untuk mendapatkan informasi kapan saja dan di mana saja. Dengan begitu, semua kalangan, terutama cendekiawan Muslim juga harus mampu menguasai teknologi informasi yang sedang berkembang saat ini seperti ponsel, email, hwitter, dan media lain yang harus dikuasai sesegera mungkin untuk menampung dan mendidik umat Islam dengan lebih baik. Masalah agidah, moral, materialistis menjadi masalah mendesak yang ditangani saat ini apalagi masalah remaja ketika dilihat dari sisi moral yang semakin menjadi tidak menguntungkan, yang seharusnya menjadi generasi penerus bangsa, tetapi mereka sekarang jauh dari kata layak dikatakan pemimpin dalam fitur. Dengan melakukan pengembangan metode dakwah, tentu juga akan memberikan rangsangan dalam segala hal kepada semua masyarakat
\end{abstract}

\section{Abstrak}

This article discusses about da'wah in society in modern era which is currently experiencing problems. Development of da'wah method must also follow the current 
era even more with the way of utilization of communication technology into a benchmark development. In the past and present of course also differ especially the method of lecture and education of Islam directly by the Ulama, Ustad, Tengku and other religious experts of course very often we meet. However, at this time of increasingly advanced information systems would facilitate the people from all walks of life to get information anytime and anywhere. That way, all circles, especially Muslim scholars must also be able to master the information technology that is growing today such as mobile phones, emails, twitter, and other media that must be mastered as soon as possible to contain and educate Muslims better. The issue of aqidah, morals, materialistic becomes an urgent matter handled today let alone the issue of teenagers when viewed on the side of morals that increasingly become unfavorable, which they should become the next generation of nation, but they are now far from the word worthy to be said leader in the feature. By doing the development of da'wah method, of course also will give stimulus in all things to all society.

\section{Pendahuluan}

\section{Latar belakang}

Agama Islam merupakan agama yang sarat dengan tuntunan dan ajaran mulia yang memberikan kemaslahatan kepada umat manusia. Salah satu tuntunan dan ajaran agama Islam adalah mengenai dakwah. Dakwah adalah salah satu bentuk aktifitas yang mulia, ia menjadi kewajiban bagi setiap muslim, dengan tujuan untuk memberikan informasi tentang islam dan mengajak orang lain agar bersedia melakukan tindakan-tindakan yang mencerminkan nilai-nilai islam. Dalam pengembangan ajaran Islam, dakwah merupakan unsur penting yang bisa menyampaikan langsung pendidikan Islam kepada masyarakat muslim. Konsep dakwah sudah diajarkan oleh Rasulullah Saw dan juga mengalami berbagai perubahan sesuai dengan era perkembangan zaman, namun penyampaian atau ajarannya tetap sama. Esensi dakwah pada dasarnya dapat dipahami sebagai upaya untuk menghimbau seseorang untuk masuk dan menjadikan seorang muslim secara totalitas, bukan pemaksaan, propaganda penyesatan seperti berusaha menggiring 
orang lain untuk mengerjakan sesuatu yang salah, ataupun kekerasan. Dengan demikian, dakwah adalah sebuah ikhtiar dalam rangkasosialisasi ajaran Islam.Dari sisi lain dakwah adalah upaya setiap muslim untuk merealisasikan fungsi kerisalahan dan fungsi kerahmatanan. Fungsi kerisalahan berarti meneruskan tugas Rasulullah saw yang patut dijadikan tauladan dalam segala budi pekertinya disetiap nafas zaman. Berkat jasa-jasa perjuangan dakwahnya menyebarkan agama Islam benar-benar membawa rahmat bagi seluruh alam, dan membawa tatanan dunia baru yang tentram dan damai. Dakwah secara umum adalah upaya menyampaikan agama Islam kepada seluruh umat manusia.

\section{Tujuan}

1.apa yang dimaksud metode dakwah

2. untuk mengetahui Problematika umat islam era modern

3.untuk mengetahui pengembangan dakwah modern

\section{Metode penelitian}

Metode kualitatif yaitu metode yang berfokus pada pemahaman dan perkembangan metode dakwah modern yang terjadi di masyarakat.

\section{Pembahasan}

\section{Metode dakwah}

metode menurut bahasa metode berasal dari bahasa Yunani methodos yang merupakan kombinasi kata meta (melalui) dan hodos (jalan), dalam bahasa Inggris metode berarti method yang berarti cara. Sedangkan dalam bahasa Arabmetode disebut thariq.Dalam kamus ilmiahpopular metode juga dapat diartikan sebagai cara yang sistematis dan tertatur untuk melaksanakan sesuatu atau cara kerja.Sedangkan pengertian metode secara istilah adalah jalan yang kita lalui untuk mencapai tujuan, atau cara teratur yang digunakan untuk melaksanakan sesuatu agar tercapai 
sebagaimana yang diinginkan.

Banyak usaha yang tidak dapat berhasil atau pasti tidak membuahkan hasil optimal, kalau tidak dipakai cara yang tepat. Berdasarkan defenisi tersebut dapat disimpulkan bahwa metode adalah ialah suatu cara yang telah diatur melalui proses pemikiran untuk mencapai suatu maksud dan tujuan yang hendak dicapai. Sementara itu yang dimaksud dengan metode dakwah adalah cara atau jalan yang ditempuh oleh pendakwah dalam mengajak manusia untuk mengerjakan kebaikan dan mengikuti petunjuk, menyuruh mereka berbuat baik dan melarang berbuat Arah metode dakwah tidak hanya meningkatkan efektivitas dakwah, melainkan pula bisa menghilangkan hambatan- hambatan dakwah. Setiap strategi memiliki keunggulan dan kelemahan. Metodenya berupaya menggerakkan keunggulan tersebut dan memperkecil kelemahannya.

\section{Problematika umat islam era modern}

Persoalan umat islam atau problematika yang terjadi dikalangan masyarakat Islam saat ini sangat memprrihatikan dan malahan menjadi hal yang sudah sangat sulit dibendung. Banyak hal yang menjadikan umat Islam saat ini menjadi seperti itu yang berakibat fatal bagi kemajuan umat Islam itu sendiri terlebih lagi dalam hal beribadah yang sebagian menyalahkan yang lain, persoalan pemahaman terhadap ajaran Islam juga menjadi banyak perdebatan saat ini. Dalam hal ini, beberapa bentuk persoalan yang terjadi di dalam umat Islam pada era modern, seperti:

\section{Aqiqah}

Seringkali tanpa disadari manusia telah mempertuhankan sesuatu selain dari Allah. Sebagai contoh dalam kehidupan sehari-hari terdapat umat Islam yang tidak memperdulikan lagi shalat hanya karena memburu materi. Uang telah menjadi "tuhan baru" dalam mengisi aktivitas kehidupannya,sehingga kebutuhan spritual dilupakan.Kemajuan dalam berbagai bidang telah membawa dampak yang sangat besar terhadap aqidah keislaman. Kemajuan itu jika dimanfaatkan secara baik akan mengokohkan keimanan seseorang. Namun tidak dapat dipungkiri pula 
bahwa kemajuan ilmu pengetahuan dan teknologi juga telah banyak membawa efek negatif bagi perkembangan aqidah keislaman seseorang.

Berbagai macam pemikiran baru muncul yang mungkin disengaja atau tidak, diadakan untuk melemahkan keyakinan akan keesaan Allah swt.

2. Akhlak

Persoalan moralitas merupakan hal yang sangat menonjol di era globalisasi ini terutama dikalangan remaja.

3. Materialisme

Di antara banyak ciri modernitas, terdapat dua ciri yang sangat menonjol yaitu individualisme dan materialisme. Sikap mental individualis dan materialis.

\section{pengembangan dakwah modern}

Hari ini bahwa kita hidup 15 abad setelah diturunkannya Islam pertama kali, kondisi sosial masyarakatnya sangat jauh berbeda dengan kondisi sosial masyarakat yang hidup saat ini. Sebab kita hidup di era modern, dimana masyarakat bisa mengakses informasi dengan begitu cepat dari belahan dunia yang lain, dan hal ini tentunya sangat berpengaruh pada pola pikir masyarakat, sehingga masyarakat semakin kritis dan masyarakat modern, akan tetapi materi yamg disampaikan kurang tepat, apalagi bila tampilan kemasannya kurang menarik, juga dakwah akan mengalami kegagalan.

Oleh karenanya, untuk mencapai tujuan dakwah yang efektif di era modern maka da'i seyogainya adalah orang yang memiliki pengetahuan dan wawasan yang luas, menyampaikan materi atau isi pesan dakwah yang aktual, dengan menggunakan metode yang tepat dan relevan dengan kondisi masyarakat modern sesuai dengan kondisi dan kemajuan masyarakat modern yang dihadapinya.Dengan demikian, dalam menghadapi masyarakat yang semakin kritis, dan tantangan dunia global yang semakin hari semakin kompleks, maka ada beberapa metode pengembangan dakwah yang dapat diterapkan, sehingga nantinya keberadaan dakwah terus melestari sesuai sesuai perkembangan zaman. 


\section{Peningkatan Sumber Daya Da'i}

$(\mathrm{SDM})$

Untuk mencapai tujuan-tujuan dakwah secara maksimal, maka perlu didukung oleh para da'i yang handal, kehandalan yang dimaksud meliputi kualitas yang seharusnya dimiliki oleh da'i masa kini, yakni adanya dua kompetensi yang dimiliki yakni: kompetensi substansif dan kompetensi metodologis. Kompetensi substansif adalah berupa penguasaan terhadap materi materi ajaran Islam secara tepat dan benar, bahkan secara universal. Kemudian kompetensi metodologis adalah kemampuan juru dakwah dalam memilih dan memutuskan pendekatan yang digunakan, termasuk pula keterampilan berpidato di atas mimbar maupun kemampuan berinteraksi dengan masyarakat. Untuk mencapai keduanya salah satu cara yang harus dilalui adalah meningkatkan kualitas pendidikan juru pendakwahnya.

\section{Pelatihan Pemanfaatan Teknologi}

\section{Modern sebagai Media Dakwah}

Salah satu langkah yang juga strategis dan efektif dalam menyebarluaskan ajaran-ajaran Islam adalah melalui media informasi, baik media cetak maupun media elektronik. Kemajuan di bidang informasi dan telekomunikasi harus dapat dimanfaatkan dengan maksimal oleh para juru dakwah, sebab dengan cara itulah, maka dakwah Islam dapat diterima dalam skala yang sangat luas dan dalam waktu yang cukup singkat.

\section{Mempertahankan Pendekatan}

Dakwah Kultural

Pendekatan dakwah kultural adalah pendekatan dakwah yang sangat strategis, hal ini, karena pendekatan dakwah kultural memiliki kelebihan di antaranya; pertama, dakwah islam dengan pendekatan kultural ini bersifat akomodatif terhadap nilai-nilai budaya tertentu secara inovatif dan kreatif tanpa 
menghilangkan aspek substansial keagamaan. Kedua, menekankan pentingnya kearifan dalam memahami kebudayaan komunitas tertentu sebagai sasaran dakwah, jadi dakwah kultural adalah melakukan pemberdayaan kehidupan beragama berdasarkan nilai-nilai sfesifik yang dimilik oleh masyarakat.

\section{Mengembangkan Pendekatan}

\section{Dakwah Struktural}

Dakwah struktural adalah dakwah yang menjadikan kekuasaan, birokrasi, dan kekuatan politik sebagai alat untuk memperjuangkan dan membumikan ajaran Islam. Dakwah dengan pendekatan struktural ini sangat strategis dipertahankan dan dikembangkan terus, karena bagaimanapun juga, dakwah sebagai sebuah proses yang melibatkan masyarakat secara luas, manakala tidak didukung secara politis maupun melalui pendekatan kekuasaan (baik melalui kebijakan legislatif maupun eksekutif), maka gerakan dakwah akan mengalami sedikit masalah, meskipun hal ini bukanlah satu-satunya penentu.

\section{Menformat Materi Dakwah yang}

Aktual dan Relevan

Secara umum, materi-materi dakwah mencakup persoalan aqidah, akhlaq, ibadah/syari'ah, dan muamalah. Namun demikian, materi yang bersifat umum tersebut, tidak akan menarik manakala tidak diformat sedemikian rupa. Kesalahan dalam memilih materi dakwah untuk kelompok masyarakat tertentu dapat mengakibatkan para jama'ah menjauh dari islam.

\section{Monitoring dan Evaluasi Program}

\section{Dakwah}

Monitoring dan evaluasi dakwah ini sangat penting untuk menemukan aplikasi dakwah yang benar-benar relevan dengan kebutuhan masyarakat. Dengan mengadakan evaluasi terhadap materi dakwah, maka diharapkan perencanaan dakwah ke depan 
akan lebih terorganisir dan tepat sasaran, sehingga pemahaman dan pengamalan agama oleh masyarakat dari tahun ke tahun mengalami peningkatan.Maka sudah sangat jelas bahwa untuk menciptakan atau mengembangkan metode dakwah di era modern diperlukan usaha yang serius, dan semua metode pengembangan dakwah yang telah dijelaskan di atas bisa menjadi acuan yang kuat demi keberlangsungan dakwah, karena memang pada dasarnya metode pengembangan dakwah itu harus selalu diperbaharui setiap generasi, setiap zaman, sehingga dakwah yang disampaikan bisa membaur dengan kondisi sosial masyarakat.

\section{Kesimpulan}

Berdasarkan uraian di atas maka dapat kita tarik beberapa kesimpulan, diantaranya adalah sebagai berikut:

1. Berdakwah merupakan kewajiban bagi setiap muslim, karna memang sebenarnya Islam adalah agama dakwah yang harus disebarkan seluas-luasnya kepada umat manusia. Untuk mengemban misi dakwah tersebut diperlukan metodemetode yang sesuai, sehingga apa yang disampaikan bisa diterima di tengah-tengah masyarakat. Metode dakwah itu sendiri diartikan sebagai suatu cara atau jalan yang ditempuh oleh seorang da'i dalam mengajak manusia untuk mengerjakan kebaikan dan mengikuti petunjuk, menyuruh mereka berbuat baik dan melarang berbuat kemungkaran.

2. Dakwah yang sampaikan oleh seorang dai kepada masyarakat sejatinya harus terus dikembangkan sesuai dengan kemajuan zaman, dai harus bisa memanfaatkan segala fasilitas yang tertsedia, seperti kecanggihan teknologi dan informasi sekarang ini. Sehingga itu akan menjadi nilai tambah untuk menunjang keberhasilan dakwah. Ada beberpa metode pengembangan dakwah yang bisa ditempuh di era modern seperti sekarang ini, seperti: Peningkatan sumber daya da'l, melakukan pelatihan pemanfaatan teknologi modern sebagai media dakwah, mempertahankan pendekatan dakwah kultural, mengembangkan pendekatan dakwah structural, menformat materi dakwah yang aktual dan relevan, dan kemudian melakukan monitoring dan evaluasi program dakwah, sehingga kekurangan-kekurangn dalam misi dakwah terus diperbaiki seiring dengan berjalannya waktu. 


\section{Daftar Pustaka}

Acep Aripudin, Pengembangan Metode Dakwah, Jakarta : PT Raja Grafndo Persada, 2011.Ahmad Warson Munawir, Al-Munawir Kamus Arab-Indonesia, Yogyakarta: Ponpes AlMunawir,1984.Aziz, Moh. Ali. 2012, A Roadmap for Rebranding Da'wah, makalah dipresentasikan pada AICIS, Surabaya, 5-8 November Iskandar dan Najmuddin, Pola Pendidikan Islam pada Periode Rasulullahdi Mekkah dan Madinah, Jurnal Lentera: Vol.13 No.3 September 2013. 
